\title{
The Assessment of Student Transitions and Purposes for Seeking a College Education
}

\author{
Kenneth W. Borland, Jr.
}

Contributors to successful student transitions to college must consider: (a) student purposes for seeking a college education, (b) transition challenges to student purposes and the successful transition into academic communities, and (c) assessing transition challenges to changes of student purposes relationships. These issues are addressed in this article, and an assessment scenario to determine the success of transition interventions is provided.

The transition to college is a series of challenges that prompts new students to consider and act responsibly in relationship to their childhood values. Challenges to their values will often solidify students' positions or dramatically stimulate change. It is held that "higher educational institutions should be involved in the shaping of values" (Pascarella \& Terenzini, 1991, p. 269). Therefore, if colleges are purposefully shaping values during the transition to college, it is most appropriate that they should also be assessing transition intervention strategies.

One value challenged in the first weeks of college is referred to as "educational" (Pascarella \& Terenzini). "Educational value" refers to what students believe about the purpose (key to any philosophy) for seeking a college education. Students' pre-college purposes for seeking a college education are challenged in the transition period, a process that influences their successful transition/integration into the academic and intellectual community.

Student affairs personnel who contribute to the successful transition of students to college, thereby retaining students for the enhancement of their learning and development, must consider three general issues regarding students' purposes for seeking a college education. First, what are typical purposes for students seeking a college education? Second, what are the challenges students face in reaching their goals? Finally, how can the relationship between transition period challenges and changes of students' purposes be assessed?

\section{Literature Review}

Throughout the history of American higher education, educators (and recently, politicians) have debated the ideal purposes for a college education (Gaff, Ratcliff, \& Associates, 1997). Proponents of liberal arts, science and research, and proponents for a professionally oriented curricula have identified sometimes unique, complementary, or

Kenneth W. Borland, Jr., D.Ed., is an Assistant Professor of Higher Education at Montana State University. 
contrary purposes for a college education.

Further, research on educational values is historically and/or generationally contextual. When referring to a particular study, the context in which it was conducted, including local and larger societal conditions for a given era, must be considered when interpreting the outcomes. This holds true even for the contemporary college student (Levine \& Cureton, 1998; Astin, 1998).

\section{Contemporary Literature}

In recent decades, the research of several higher educators broadly described the more contemporary purposes for a college education. Levine (1978) identified four educational purposes for college attendance upon which faculty build curriculum:

1. Progressivism: building on life experience (student-centered, problem oriented)

2. Perennialism: training the rational faculties of the mind

3. Essentialism: learning a prescribed knowledge, cultural heritage

4. Reconstructionism: reconstructing society

As they addressed perspectives on educational purpose at the college level, Stark and Lattuca (1997) supported the lasting validity of Levine's four purposes. However, they concluded that he "left out" two purposes likely to be found within particular institutional types. For the purpose of this article, these two purposes are defined as:

5. Vocationalism: preparing for work/tasks

6. Valuism: enhancing moral/spiritual/valuing development

Astin (1998) approached the purpose for a college education longitudinally, tracking for over thirty years the college freshman's purpose for seeking a college education (1966-97). This study was aimed at determining the differences in freshmen's intrinsic (developing a meaningful philosophy of life) or extrinsic (desiring to be well off financially) purposes.

While there are numerous ways to label and organize purposes for a college education, contemporary students often couch their purposes in utilitarian terms. Studies indicate that many students would agree with one of the following purposes for obtaining a college education: to develop the abilities of my mind and to be a better thinker; to better understand the world, my culture and the cultures of others; to solve problems and to learn from my life experiences; to critically reflect on society and to change my world; to gain specific work/task related skills to get a job; or to develop as a whole so I can better determine values/priorities.

\section{Transition Challenges}

"Challenge and support, involvement, marginality and mattering, and validation [are] conditions that are found (or not found) in the college environment" (Evans, 
Forney, \& Guido-DiBrito, 1998, p. 25). They can, in the transition period, independently or interactively affect students' development and their purposes for a college education. Since one's philosophy of life is the root for one's educational philosophy, challenges to life values might also challenge one's purpose for seeking a college education (Terenzini, 1996; Tinto, 1998). Challenges can be interpersonal, academic, or economic, or a combination of the three.

\section{Interpersonal Challenges}

Associations with individuals or groups, including parents, siblings, friends, extended family, or peers, can contribute to the formation of a desire for seeking a college education. Mentors such as a high school teacher or counselor can contribute to this goal as well.

At college there will be new challenges to students' educational values from new college associations; e.g., new friends, neighbors, counselors, and academic and professional mentors. Interpersonal challenges to students' purposes for seeking a college education will also develop via involvement in student organizations, whether they are political, religious, pre-professional, social, recreational, service, ethnic, or greek. Informal interpersonal college associations beyond these will challenge students to consider and act upon their purposes for seeking a college education.

\section{Academic Challenges}

Coursework initiated and completed during the transition to college period can also challenge students to consider and responsibly act upon their purposes for seeking a college education. The content and pedagogy of general education courses often challenge students' perception on what it means to obtain a college education. General education is designed to encourage self-discovery and one's relationship with others. Written and verbal communication, mathematics, the arts, humanities, natural and social sciences, multicultural/global perspectives, and information technology are all part of general education goals (Gaff, Ratcliff, \& Associates, 1997).

Freshman seminar courses should challenge students' goals and values, and may, by design, be more intentional in challenging students' purposes for seeking a college education. The Montana State University (MSU) General Studies Program (GSP) freshman seminar course for undeclared freshmen includes purpose challenges. It addresses the value of education; community service; major and career exploration; a student "Search for Meaning" paper based on Frankl's (1985) book, Man's Search for Meaning; social equity; public speaking; and health and wellness. The seminar faculty also encourages and initiates relationships between transition students, classroom facilitators, peer leaders, and seminar classmates.

\section{Economic Challenges}

No doubt, students have a variety of economic assets and difficulties. Some are dependents of the well-to-do while others are independent or impoverished. Some are 
more adept at handling personal finances. Yet, without regard for students' financial states, all students have philosophical positions regarding money. Students do have to make decisions (within their philosophical context) that have short and long term economic ramifications. Transition students are faced with financial events that can threaten their opportunities for a college degree. No matter the short or long-term effects of financial distress, the economic challenges can force students in transition to consider their purposes for seeking a college education.

\section{Assessing Your Transition Program}

While assessing individual students facing challenges to their purposes for seeking a college education is rather commonplace, college-wide student affairs assessment of student transition and development success requires a more systematic approach. The following strategies are helpful.

First, determine what you, as a division and as an institution value. In relation to your institutional mission, identify and state (in operational terms) your program's goals and desired outcomes. Secondly, determine how you will measure and evaluate your program in regard to your stated program goals and desired outcomes, design and implement a data gathering, management, and analysis strategy related to your group(s) of students. Finally, determine what action must be taken to adjust your program's goals and outcomes and/or your current strategies to reach its goals and outcomes.

\section{Step 1: What Do You Value?}

After the 600 undeclared, traditional aged, entering freshmen at Montana State University complete summer orientation, they are automatically enrolled in the General Studies Program freshman seminar. The seminar mission statement states that, "Successfully integrating entering students into the academic and intellectual community at Montana State University remains the cornerstone of the freshman seminar course." Three of the seminar's eight published, mission-related, desired objectives relate to students' purposes for a college education. A grant-funded team was established to assess this transition program in terms of what it valued. Specifically targeted for assessment were:

1. the goal of helping students successfully make the transition/integration into MSU's academic and intellectual community.

2. the impact of the seminar on the immediate and longitudinal evolution of students' purposes for seeking a college education; therefore, students' integration into the MSU academic and intellectual community.

3. the impact of other undergraduate experiences on the immediate and longitudinal evolution of students' purposes for seeking a college education; therefore, students' integration into the MSU academic and intellectual community.

The identification of these goals was assisted by preexistence of a well-articulated document that, in relation to the MSU mission, identified and stated goals and outcomes 
in operational terms. If such documents do not exist at an institution, a first step would be to conduct focus groups or interviews with program personnel to generate a working list of program goals and desired outcomes.

\section{Step 2: How Will You Measure and Evaluate?}

The Montana State University team designed three instruments to assess students' changes of purpose for a college education in relation to the kinds of challenges they encounter. The pre-seminar, post-seminar, and longitudinal questionnaires were subjected to typical research instrument design processes; i.e., they were checked against the literature, pilot-tested, refined, and submitted for external expert critique. The team also discussed when and how to administer the instruments in order to achieve the most representative participation and data, as well as the appropriate use of statistical and qualitative analysis. The strategy became administering the pre-seminar questionnaire during the summer orientation, the post-seminar questionnaire in the last week of the fall seminar, and the longitudinal questionnaire annually in the middle of the spring semester. Initial measurements were gathered using paper and pencil responses, and future administrations will be done via the web page.

Step 3: What Actions Must be Taken?

Use of the analysis data to adjust program goals, strategies, processes, and outcomes is critical. At Montana State University, results were reported and included in its own global assessment effort. It was discovered that much of students' purposes for seeking a college education and making transitions into the academic and intellectual community are challenged by the larger undergraduate experience.

GSP leadership, staff, and seminar faculty were given the results for program level action and will adjust its goals and/or desired outcomes as indicated. The opportunities for campus-wide use of the assessment are enormous; however, it should be noted that no matter who receives the report, the end of assessment is always action.

\section{References}

Astin, A. W. (1998). The changing American college student: Thirty-year trends, 19661996. Review of Higher Education, 21, 115-35.

Evans, N. J., Forney, D. S., \& Guido-DiBrito, F. G. (1998). Student development in college: Theory, research, and practice. San Francisco: Jossey-Bass.

Frankl V. (1985). Man's search for meaning (Rev. ed.). New York: Pocket Books. Gaff, J. G., Ratcliff, J. L., \& Associates (Eds.). (1997). Handbook of the undergraduate curriculum: A comprehensive guide to purposes, structures, practices, and change. San Francisco: Jossey-Bass.

Levine, A. (1978). Handbook on undergraduate curriculum. San Francisco: JosseyBass.

Levine, A. \& Cureton, J. S. (1998). When hope and fear collide: A portrait of today's college student. San Francisco: Jossey-Bass. 
Pascarella, E. T. \& Terenzini, P. T. (1991). How college affects students: Findings and insights from twenty years of research. San Francisco: Jossey-Bass.

Stark, J. R. \& Lattuca, L. R. (1997). Shaping the college curriculum: Academic plans in action. Needham Heights, MA: Alllyn \& Bacon.

Terenzini, P. T, et. al. (1996). Making the transition to college. In Robert J. Menges, Maryellen Weimer, \& Associates (Eds.), Teaching on solid ground: Using scholarship to improve practice (21-42). San Francisco: Jossey-Bass.

Tinto, V. (I 998). Colleges as communities: Taking research on student persistence seriously. Review of Higher Education, 21, 167-77. 